\title{
ICT INTEGRATION IN THE EDUCATIONAL SYSTEM OF PHILIPPINES
}

\author{
Queenie Pearl V. Tomaro' ${ }^{1}$, Dyah Mutiarin ${ }^{2}$ \\ ${ }^{1}$ Lecturer, Department of Political Science, Mindanao State University- Iligan Institute of \\ Technology \\ ${ }^{2}$ Lecturer of Govermental Science, Universitas Muhammadiyah Yogyakarta \\ ㅁqeenietomaro@gmail.com; ${ }^{2}$ dyahmutiarin@umy.ac.id \\ DOI: https://doi.org/10.18196/jgpp.5399
}

Article Info

Article history:

Received 02 Sep 2018

Revised 17 Nov 2018

Accepted 30 Nov 2018
Keywords:

Technological advancement; education; ICTintegration

\section{ABSTRACT}

The paper aims highlight the state of ICT integration to the educational system of the Philippines, including the challenges, efforts, and possible solutions. The study is a review of two scholarly works focusing on the case of ICT integration in the educational system of Philippines. The paper reviewed were the paper of Kubota, Yamamoto, and Morioka (2018) entitled, Promoting ICT education in developing countries: Case Study in the Philippine and the research work of Bonifacio (2013) entitled, Developing Information Communication Technology (ICT) Curriculum Standards for K-12 Schools in the Philippines. The critical analysis of the reviewed papers revealed several policy actions to fully integrate ICT in education in the case of Philippines such as added trainings for teachers, provision of computer infrastructures, integration of ICT in the curriculum in a strategized manner, and lastly a strong leadership. The paper provided a lens both on the problematic situation on the actual school set-ups and also the possible key steps to be undertaken for improvement. It is a review of the selected academic papers which delves into the ICT-Integration in the Educational System of Philippines. The formal efforts of the government were also highlighted including the prime importance of ICT in education. The paper does not only embolden a problem of the inadequacy of the school facilities but it highlights how this problem affects the competitiveness of Filipinos in the job market and the backwardness of the standing of the country in technological advancement

\section{ABSTRAK}

Makalah ini bertujuan menyoroti keadaan integrasi TIK ke sistem pendidikan Filipina, termasuk tantangan, upaya, dan solusi yang mungkin. Penelitian ini merupakan tinjauan atas dua karya ilmiah yang berfokus pada kasus integrasi ICT dalam sistem pendidikan Filipina. 
Makalah yang ditinjau adalah makalah dari Kubota, Yamamoto, dan Morioka (2018) berjudul, Mempromosikan pendidikan TIK di negara-negara berkembang: Studi Kasus di Filipina dan pekerjaan penelitian Bonifacio (2013) berjudul, Pengembangan Standar Kurikulum Teknologi Komunikasi (TIK) untuk Sekolah K-12 di Filipina. Analisis kritis dari makalah yang ditinjau mengungkapkan beberapa tindakan kebijakan untuk sepenuhnya mengintegrasikan ICT dalam pendidikan di Filipina seperti pelatihan tambahan untuk guru, penyediaan infrastruktur komputer, integrasi ICT dalam kurikulum dengan cara yang strategis, dan terakhir kepemimpinan yang kuat. Makalah ini memberikan lensa baik pada situasi problematik pada pengaturan sekolah yang sebenarnya dan juga kemungkinan langkah-langkah kunci yang harus dilakukan untuk perbaikan. Ini adalah tinjauan makalah akademis terpilih yang menyelidiki Integrasi TIK dalam Sistem Pendidikan Filipina. Upaya formal pemerintah juga disoroti termasuk pentingnya ICT dalam pendidikan. Makalah ini tidak hanya memperkeras masalah kekurangan fasilitas sekolah tetapi menyoroti bagaimana masalah ini mempengaruhi daya saing warga Filipina di pasar kerja dan keterbelakangan dari negara dalam kemajuan teknologi..

\section{INTRODUCTION}

The paramount importance of education as the key to develop a country rationalizes the government's thrust to re-calibrate the educational system for increased competencies and added skills in the labor force. The Incheon Declaration on Education Framework for Action, made during the World Education Forum in Incheon, South Korea re-committed the effort to the attainment of the vision for Education and the 2030 Sustainable Development Goals, especially the fourth Sustainable Development Goal which is: 
Ensure inclusive and equitable quality education and promote lifelong learning opportunities for all.

As part of the goal of providing an inclusive quality education, teachers must be given fundamental consideration: the number, the quality, the capacities, and competencies. Thus, the SDG 4 further stated:

By 2030, substantially increase the supply of qualified teachers, including through international cooperation for teacher training in developing countries, especially least developed countries and small island developing States (SDGs)

Consequently, as an embracement to the modernizing world, education has evolved as one of the main thrust of Information and Communication Technology. ICT is now developed as one of the main infrastructures that every educational institution should provide its students with. Information and Communication Technologies or ICT is an umbrella term that comprises any communication device or application, such as; radio, television, cellular phones, computer, and network hardware and software, satellite systems and many others, as well as the various services and applications associated with them, such as videoconferencing and distance learning (Kumar, 2008). Kumar (2008) stated that 'when such technologies are used for educational purposes, namely to support and improve the learning of students and to develop learning environments, ICT can be considered as a subfield of Educational Technology'. Not only is ICT 
262 important as a learning course but also ICT materials such as software and multimedia, are used to supplement instruction (Bonifacio, 2013) and it provides ease to teacher's in tasks such as, computing of grades, writing reports, and etc.; tasks that was to be done manually using hands before.

In adoption of the fast advancing technological developments in the international arena, the education sector, the teachers primarily, must be provided with trainings and workshops for the integration of ICT in the learning curricula. This is vital not only for the quality education that will be afforded to the students but also for the internal development of the Department of Education as an organization in itself. It also puts pressure on the quality and access of education and on how to keep pace with the development of new digital technologies, and the transition to a knowledge-based economy (Bonifacio, 2013). The currently emerging knowledge-based economy elevates knowledge as 'the most precious asset driving growth, wealth-creation, and employment, and education serves as the key to economic and social mobility' (Bonifacio, 2013). This is why ICT education is vital in the current age and on how it is integrated to education, how accessible and functional are the facilities, and on how capable and knowledgeable the teachers are, directs the course of ICT and its impact to the development of the country. Hence, human performance in organizations, such as the Department of Education, reflects on the knowledge, skills, behaviors, and values and added or expertly performed abilities and 
skills, and these will help the organization to perform better and to increase productivity; which is why 'any expenditure on education and development is considered a long term investment that the organization can benefit from (Rafiei \& Davari, 2015). Not only is it for the benefit and productivity of the organization but also for the quality and outcomes of its services. In light of this forwarded notion, investment to not only facilities and infrastructures for ICT-led learning but also to the trainings and workshops that must be provided to the teachers and staff must also remain as a priority to effectively provide ICT literacy.

In providing a deeper look into the integration of ICT to the educational system of the Philippines, several papers will be reviewed. The first paper is the paper of Kubota, Yamamoto, and Morioka (2018) entitled, Promoting ICT education in developing countries: Case Study in the Philippine. The second paper is a research work of Bonifacio (2013) entitled, Developing Information Communication Technology (ICT) Curriculum Standards for K-12 Schools in the Philippines. These papers were handpicked to not only provide an understanding of ICT in the Philippine Educational setting but also how ICT integration to education evolved after the new educational system was set up under the Aquino administration.

The first reviewed paper was written by Kubota, Yamamoto, and Morioka (2016) entitled, Promoting ICT education in developing countries: Case Study in the Philippine. The paper generally highlighted the ICT education settings through a depiction of the situation in 
264 two schools from the rural (100 kms from Manila) and suburbs (50 $\mathrm{kms}$ from Manila). It was first and foremost emphasized that despite the wide adoption of ICT in developed countries, in the Philippines, a developing country, there is a gap of accessibility present between rural and urban areas of the country. This said gap was grounded by Kubota, Yamamoto and Morioka (2018) in the educational setting by delving into the ICT-adoption statuses of schools in the country. The need for ICT integration to the educational set-up of the schools are given emphasis as it is part of the goal of the government of the Philippines that 'a people-centered inclusive and developmentoriented information society, where everyone can create, access, utilize and share information and knowledge', is established (Kubota, Yamamoto, and Morioka, 2018: 3). Also, the new millennium ushered in an information revolution that puts pressure to the countries to catch up to the latest technological developments. One of the key policy actions of the government, under the Department of Education was the introduction of the subject, Technology and Home Economics (THE), a subject combining the Home Economic and Livelihood Education (HELE) in the secondary level (Magno, 2006; Kubota, Yamamoto, and Morioka, 2018). Furthermore, Kubota, Yamamoto, and Morioka (2018:3) also highlighted the key policies of the Philippine Department of Education that emboldens the integration of ICT in the curriculum of education. These are as stated: 
- Technology must be studied as a separate subject, and then applied to other learning areas as a tool for learning how to learn.

- Teaching-learning must not be textbook-driven but should include the application of ICT, whenever appropriate.

- An education modernization program will equip schools with facilities, equipment, materials and skills, and introduce new learning and delivery system, capitalizing on recent technological developments

In addition, the Philippine Department of Education introduced the Basic Education Curriculum (BEC) integrating ICT through the following key mandates:

1. School computerization

2. Teacher training

3. IT curriculum development

4. Multimedia content development

5. Financing

6. Monitoring and evaluation

Following this policy effort, is the introduction of the Philippine Education Technology Master Plan which has the following operational targets (Bonifacio, 2013: 5): (1) all public secondary schools shall be provided with an appropriate educational technology package; (2) $75 \%$ of public secondary schools shall have a computer laboratory room equipped with basic multimedia equipment; (3) all public secondary schools shall have an electronic library system; (4) 75\% of 
26. public secondary schools teachers shall have been trained in basic computer skills and the use of the Internet and computer-aided instruction; and (5) all learning areas of the curriculum shall be able to integrate the application of ICT, where appropriate.

The research of conducted interviews and the results of the research revealed not only the depth but the wide size of the limited ICT adoption in the educational institutions subjected for study. The results of the study of Kubota, Yamamoto, and Morioka (2018) are thematically divided into the following themes of analysis: infrastructures, human resource, and financial resource. Firstly for infrastructure status, it was emphasized in the result of the study that in the rural school chosen as one of the research foci, there was a very scarce number of computers reaching only 10; with only 6 among the 10 were fully functional for offline computer work. These computers were expected to cater 1400 students. The computers were also not connected to the internet and were not used effectively. Water leakages from leaking roofs are causing damage to the computers which also lack computer maintenance. Furthermore, there was unstable power supply in the area and the fluctuating supply of electricity is detrimental to the present scarce computer facilities. The second school in the suburbs was revealed to have 10 computers with only 8 among the 10 are in fully-functioning status. But same as the situation of the other school, computers were not connected to the internet despite the availability of internet signal in the area. Thus, computers can only be used for minimal work. Furthermore, Kubota, 
Yamamoto, and Morioka (2018) revealed that the computers were said to break down easily and that computers were always locked inside a room so teachers cannot easily have access.

Secondly in Human resource, it was mainly revealed that there is no skilled personnel that is capable of basic computer repairs. Teachers were revealed to possess low computer skills and knowledge about software and hardware. This is supported by the results of the study of Caluza et al. (2017) revealing that most of the public school teachers they have assessed have basic knowledge on ICT and are in need of improvement. In addition, there is no technical support staff to maintain the functionality and usability of computers and teachers were given very limited training due to their (teachers) hectic schedule. In the situation of the second school studied by Kubota, Yamamoto, and Morioka (2018) it was revealed that teachers did not have a learning opportunity for training and no technical support staff was present hence repairs or any basic damage cannot be given immediate solution. Teachers were also revealed to lack computer knowledge and skills for instructional purposes and lacked the motivation to teach computer-related topics as mentioned 'it was not mandated to use computers in classrooms' (Kubota, Yamamoto, and Morioka, 2018). According to Kubota, Yamamoto, and Morioka (2018), the Philippine Department of Education provides teachertraining courses to high school teachers and principals (school heads) several times a year to promote the ICT literacy but these are only present in 'big' cities such as Manila and Cebu. More trainings must 
268 be provided to the teachers for an effective integration of ICT in teaching and other related task assigned to the teaching force in order to uplift and enhance the quality of education in schools (Caluza et al., 2017).

Thirdly in budgetary challenges and financial resource status, it was revealed by Kubota, Yamamoto, and Morioka (2018) that there was no budget for computer maintenance hence the 4 computers are dusting in the corners with no provision for repair. Also, there was no budget for internet connection hence computers remained to be unconnected and can only be used for very minimal offline work. The second school remained to be of the same set of problems; no budget for computer maintenance and despite the internet signal present in the area, there was no budget for internet connection provision.

The following results in the study of Kubota, Yamamoto, and Morioka (2018) revealed as surfacing challenges of ICT integration in the education setting. Kubota, Yamamoto, and Morioka (2018) analyzed these challenges to be connected in a perpetuating cycle. This cycle shows an analysis of the situation of the interconnectedness of the factors that continue to hinder the effective integration of ICT in education. This cycle is presented below: 
Figure 1

Situations of Two analyzed cases of ICT in Education setting

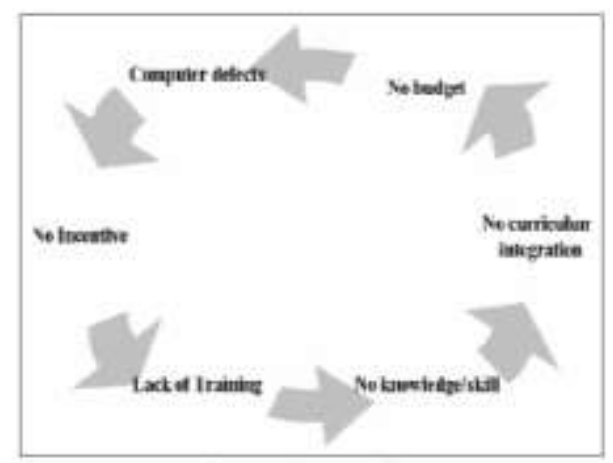

Source: Kubota, Yamamoto, and Morioka (2018)

Kubota, Yamamoto, and Morioka (2018) described the challenges presented in Figure 1 to be in a vicious cycle that must be addressed all together in order to effectively integrate ICT in education. In light of this, Kubota, Yamamoto, and Morioka, (2016) suggesting the following options: (1) collaboration with third party organization, i.e. Kansai University, (2) Kansai University, to provide large-scale trainings, workshops, and seminars to teachers, (3) Collaboration with Bulacalan State University for technical support and computer maintenance. The framework for collaboration that Kubota, Yamamoto, and Morioka (2018) have forwarded is presented in Figure 2 below. 
Figure 2

Framework for Collaboration

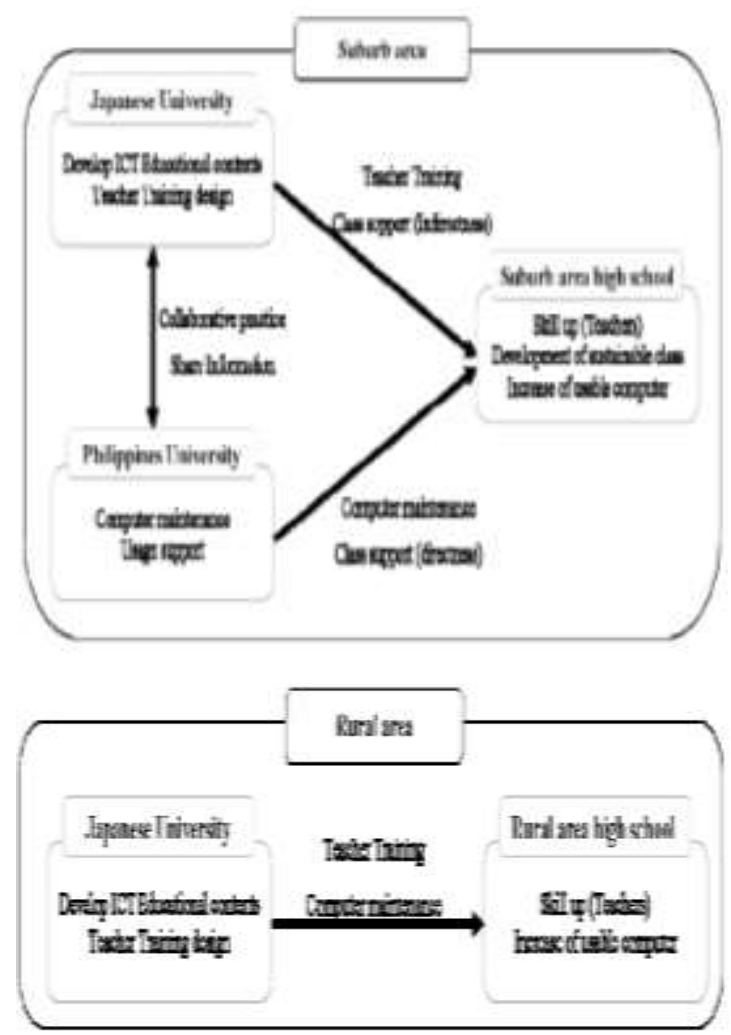

Source: Kubota, Yamamoto, and Morioka (2018)

Kubota, Yamamoto, and Morioka (2018) provided a very detailed depiction of the ICT in two schools in the Philippines, Its strength rests upon the clear details which aided a thorough understanding of the situation in suburban and rural located schools. It also provided viable solutions that can be explored to resolve the problems presented. However, one of the weaknesses of the research is that it only focused on two schools; 1 in the suburban area and 1 in 
the rural area. Two schools do not present a strong and complete picture that would generalize a digital divide between the rural, suburban, and urban areas. Furthermore, the paper has focused more on the existence of computers and its functionality and less on the integration of ICT in the curriculum as a learning focus.

While the first paper of Kubota, Yamamoto, and Morioka (2018) generally discussed about the situation of ICT integration in the schools in suburban and rural areas of the Philippines, the second paper that is reviewed in this paper is about the ICT integration in the new educational system of Philippines introduced under the administration of former president Benigno Aquino III. The paper is entitled, Developing Information Communication Technology (ICT) Curriculum Standards for K-12 Schools in the Philippines.

The paper, as well-illustrated in its title, aims to forward the need to design a curriculum standard for ICT integration in the K-12 educational system of the Philippines. In addition, the study of Bonifacio (2013) argued the vitality of ICT in education especially in the modern age of technological advancement and on how ICT shouldn't drive education but that educational goals must drive the use of ICT in schools. Hence, the paper emphasized how important for schools to develop curriculum standards that would set clear educational expectations from students, improve instructional strategies for teachers, and provide a framework for schools for technological integration. 
The paper also intensively addressed the question on why ICT-integration is indispensable. One highlighted reason is on the vitality of ensuring that the Filipino students are able to acquire ICT concepts and skills that will help them achieve greater benefits of learning (Bonifacio, 2013). Furthermore, the paper also emphasized how ICT can best be integrated in the curriculum of the new K-12 system. Bonifacio (2013) founded the core of its paper on the theory of Pattinson and Berkas (2000) which generally laid down four steps on integrating ICT standards in the curriculum.

The four steps being exemplified define the process of an effective ICT integration in the educational curricula. These four steps are the following (Pattinson \& Berkas, 2000; Bonifacio, 2013): (1) developing a curriculum framework in the context of standardsbased reform; (2) selecting a curriculum-planning model that further articulates the standards-based reform outlined in the framework; (3) building capacity at all levels of the educational system; and (4) monitoring, reflecting upon, and evaluating the curriculum as teachers implement it in the classroom. This entails a curriculum development that would direct educators into targeting skills for every grade level and into focusing the instructional activities and assessments about the target skill.

The second core of the paper was the discussion on how ICT can best improve the instructional element in educational institutions. The benefits of ICT that Bonifacio (2013) extensively discussed says to not lie on the outputs and ease of work alone but it 
also includes the support that ICT provides in new instructional approaches and methods for more feasible cooperative learning experiences for students. The recognition of ICT as a valuable asset for education was grounded on how it improves student learning outcomes and effectiveness and how it provides the teachers options of their own pedagogical preferences (Choy, Suan \& Chee, 2012; Bonifacio, 2013).Thus, Bonifacio (2013) argued that in order to effectively utilize ICT in improving the quality of education and heighten teaching efficiency, pre-service training and programs that are relevant and responsive to the needs of the education system' must be provided. This is to provide teachers sufficient subject knowledge, a repertoire of teaching methodologies and strategies, professional development for lifelong learning and for them to be exposed on the new channels of information. Bonifacio (2013) did not fail to point out that programs of personnel development for teachers about ICT is important but he also emphasized that the focus is on learning the technology and not on teaching as ICT is not to be used as an alternative for teachers but as tools for a more effective pedagogy.

The final part of the paper of Bonifacio (2013) tackled the challenges that the integration of ICT to education would bring forth and on what the government of the Philippines have done and should do in addressing the challenges. The paper revealed that developments in the integration of ICT in education has been fruitful and the facilitation by the Department of Education, and 
274 collaboration with the private sector in several initiatives successfully equipped a number of schools with ICT facilities but these initiatives have not insured that teachers fully use the facilities for teaching purposes (Belawati, 2004; Bonifacio, 2013). In light of this, Bonifacio (2013) presented an implementation plan for ICT integration in the education setting. He presented in details the parameters set up under the National Strategic Planning Initiative for ICTs in Basic Education launched by the Philippine Department of Education in February 2005 as part of the effort of the government for a systemwide reform process aiming to alleviate the Philippine basic education out of crisis. These parameters that Bonifacio (2013) presented are the following: Appropriateness, Effectiveness, and Sustainability. Supplementing these government efforts, Bonifacio (2013) exemplified the need for ICT training of the faculty force. It was emphasized in the paper that student's use of technology represents the teacher's integration of technology into teaching and curricula and also affects the teacher's effectiveness and that students' academic achievements are noticeably influenced by the teacher's use of technology (Chang, 2012; Bonifacio, 2013). This provides rationalization in increasing the need to increase teacher's technological literacy. The technology-related knowledge of the teachers reflect the achievements and educational performance of their students. In addressing concerns of the teachers' poor computer literacy, the paper of Bonifacio (2013) provided several proposed actions as cited from (Almekhlafi and Almeqdadi (2010)). These 
proposed action are the following: (1) deliver workshops on effective technology integration; (2) provide teachers with appropriate ICT tools in the classroom; (3) provide teachers with incentives and awards for outstanding technology integration in their classrooms; (4) provide teachers with some release time so that they can plan effectively for technology integration in teaching and learning; (5) explore the use of technology in classrooms covering all school levels, including public and private schools; (6) investigate the effect of technology integration on students' achievement and attitude; (7) evaluate technology integration in relationship to curriculum goals and outcomes (Bonifacio, 2013: 7).

Bonifacio (2013) also added the importance of an effective technological leader in the person of the school administrators who are experienced and capable and are able to receive training in vision, planning and management. School administrators are instrumental in designing professional development plans from the set technological targets (Chang, 2012; Bonifacio, 2013). Bonifacio (2013) also highlighted the need to more than just integrate ICT as a subject course but to device a systematic development plan thwarting the fears of the teachers and users in general of the use of technology. The challenges of that the integration of ICT to education faces is more than just infrastructure-wise but also system-rooted. The lack of facilities hinders the effective integration and the scarce computers in schools limits the extensive learning experience for both teachers and students. The study of Cajilig (2009) reinforced this claiming stating 
276 that 'while the enthusiasm level for integration was high, the extent of ICT implementation was poor mainly due to the lack of computer facilities and teacher training programs'. The teachers' knowledge, skills, and attitude towards ICT integration is also a challenge that must be addressed. Resistance to technological introduction and educational reform is always a present hurdle but an effective technological leader is always needed to facilitate the acceptance and adoption through trainings, workshops, and seminars. The effective development of ICT curriculum standards and its integration to the educational system would only be effective is the challenges are met with the forward-looking acceptance that technology has to be embraced than feared.

Supplementing the presented challenges of ICT integration in educational institutions, a paper of Arinto (2006) highlighted a framework for an effective integration. Arinto (2006) also emphasized the essential role of ICT in education. Arinto (2006) stressed that an effective integration of ICT in education programs is expected to "develop not only technology literacy but also, and especially, information literacy, critical thinking, and other skills needed to enable teachers and learners to transform information into useful knowledge." Hence, both the papers of Bonifacio (2013) and Kubota, Yamamoto, and Morioka (2018), did not only point out the current challenges of ICT-integration in the educational institutions, and the challenge it poses to the human resource of the education sector but it also highlighted the call for technological adoption, 
integration in the curricula, and professional development in the technological field in order to effectively deliver educational services to the students that is in keeping with the rapidly advancing modern world and the technology-rooted requirements of the competitive job market.

\section{CONCLUSION}

Technology is not a separate realm from education as a matter of fact, technology is penetrating all realms but the appreciation of technology lies into how it is accepted, adopted, and integrated to every system. In fact, the study has highlighted the existing efforts of the government of the Philippines in revamping its technologyoffered education through the integration of ICT in the basic education curricula. The study presented that it only through adoption and utilization can technology be useful and meaningful in the development of one organization and its outputs. Thus, teachers and school systems must work together in pursuing technology integration at an optimal level where innovative technology-based approaches to teaching and learning are adopted and integrated in the learning curricula (Limon, 2015). Hence, in the education sector of the Philippine government technological knowledge is given importance. ICT is now taught in schools but the study highlighted several challenges that threaten the quality of technological training among Filipino students. The challenges are rooted in the following areas: Infrastructure and facilities (computers and etc.), human 
278 resource (limited training for teachers, lack of motivation, and low technological knowledge), and lastly the need for a technological leader that would play a pivotal role in effectively integrating ICT in the curriculum. The study argued the inadequate infrastructure and computer equipment available for educational usage in the schools in the Philippines. This provides a detriment to the development of computer literacy among students and would just further the digital divide among rural and urbal school-goers. Secondly, the lack of human resource in ICT teaching limits the extent of exposure, the quality of ICT training, and the content of ICT education being taught in schools hence, the study reiterated the important role of qualified human resource in ICT education. Lastly is a technological leader. The study emphasized that the existence of a visionary technological leader- one that does welcomes innovation and technological advancement-greatly affects the ease and transition of ICT integration in the educational system.

In sum, the study highlights the importance of ICT-targeted interventions from the government. The world is in consense that the job market, alongside the technological advancement, require computer-literate job applicants thus, the instrumental role of educational institutions in integrating ICT in the learning plan is of utmost importance and time-relevance. More importantly, however, the role of the government and of the heads of educational institutions in promoting ICT in Basic Education must also be firm and genuine. Equitable provision of ICT education among all 
Philippine schools and the increase of ICT infrastructure provisions must be prioritized. For Filipinos to be globally competent, adoption of the technological trend must be integrated to the school's basic education. Development of one country, rest upon how it caters changes and innovation and smoothly transitions towards an upward slope of progression.

\section{IMPLICATIONS}

The results of the study imply an intervention from the government and other societal forces that would fill the lacks and inadequacies of the ICT adoption in education. Trainings that would capacitate teachers and counter negative attitude toward ICT-use as well as re-vamping of the curricula that would advance the ICT competence of the students must be prioritized. More importantly, existing equipment such as functioning computer units with installed programs for educational purposes and have internet connections must also be looked into. The absence of exposure to technology also heightens the divide and the technology-linked anxiety. Lastly, technological leaders with knowledge, vision, and open acceptance of the adoption, usage, and education of the technological advancement, must also emerge in every schools and organizations; technological leaders in the person of the school principals, school directors/directress, and the members of the faculty. The study highlights a call for intensified government support to schools. It is the responsibility of the state, through its educational institutions and 
280 its government that the people of the Philippines are equipped with the knowledge and competencies needed in entering the global market and the job industry. The integration, therefore of ICT, is a crucial move that must be aided by curricula adjustments, human resource availability, and infrastructure provisionOne of the main functions of state existence beside to development and implementation of protection function is the obligation to provide public services in the form of goods and services in accordance with the needs and expectations of the community. Through public services, the needs of the community, especially the basic needs could be fulfilled and the various problems that arise in society can be resolved.

\section{REFERENCES}

Almekhlafi, A. G., \& Almeqdadi, F. A. (2010). Teachers' Perceptions of Technology Integration in the United Arab Emirates School Classrooms. Educational Technology \& Society, 13(1), 165175.

Arinto, P.B. (2006). Reflections on ICTS in basic education policy and practice in the Philippines. Paper presented at the 2nd National ICTs in Basic Education Congress, Waterfront Hotel, Lahug, Cebu City, Philippines, 6-7 September

Belawati, T. (2004). UNESCO M eta-Survey on the Use of Technologies in Education, ICT Use in Education in the Philippines. http://unesdoc.unesco.org/images/0013/001349/134960e.pdf

Bonifacio, A. (2013). Developing Information Communication Technology (ICT) Curriculum Standards for K-12 Schools in the Philippines. Paper presented at the The Sixth Conference of 
M IT's Learning International Networks Consortium (LINC), M IT, Cambridge, Massachusetts, USA.

Cajilig, N. (2009). Integration of Information and Communication Technology in Mathematics Teaching in Metro Manila Public Secondary Schools. Education Quarterly, UP College of Education, 67(1), 79-91.

Caluza, B., Las Verecio, R., Grace D. Funcion, D., A. Quisumbin, L., A. Gotardo, M., Lester P. Laurente, M., . . . Marmita, V. (2017). An Assessment of ICT Competencies of Public School Teachers: Basis for Community Extension Program (Vol. 22).

Chang, I. (2012). The Effect of Principals' Technological Leadership on Teachers' Technological Literacy and Teaching Effectiveness in Taiwanese Elementary Schools. Educational Technology \& Society, 15(2), 328-340.

Choy, M., Suan, K. \& Chee, L. (2012). Enabling Learning at the Workplace - Humans first, Technology second: Adopting a Best-Fit Approach to Implementing ICT in Training.

Education 2030 : Incheon Declaration and Framework for Action for the implementation of Sustainable Development Goal 4. http://unesdoc.unesco.org/images/0024/002456/245656e.pdf

Kubota, K., Yamamoto, R., \& Morioka, H. (2018). Promoting ICT education in developing countries: Case Study in the Philippine.

Kumar, R. (2008). Convergence of ICT and Education. World Academy of Science, Engineering and Technology International Journal of Information and Communication Engineering, 2(4).

Limon, M. (2015). Home Economics Teachers' Usage of Information and Communication Technologies in Hong Kong and in the Philippines and its Implications. International Journal of Academic Research in Progressive Education and Development, 4(4), 21-30. doi: 10.6007/IJARPED/v4-i4/1865

Rafiei, N., \& Davari, F. (2015). The Role of Human Resources Management on Enhancing the Teaching Skills of Faculty Members. Materia Socio-Medica, 27(1), 35-38. doi: 10.5455/msm.2014.27.35-38 
282 Pattison, C. \& Berkas, N. (2000). Critical issue: integrating standards into curriculum. Retrieved January 1, 2018 from www.ncrel.org/sdrs/areas/issues/content/currclum/cu300.htm

United Nations. 2015. Transforming our world: the 2030 Agenda for Sustainable Development. https://sustainabledevelopment.un.org/post2015/transforming ourworld. 